\title{
3. Modelling development and growth of the potato crop influenced by temperature and daylength: LINTUL-POTATO
}

\author{
P.L. KOOMAN ${ }^{1,2}$ and A.J. HAVERKORT ${ }^{1}$ \\ ${ }^{1}$ DLO-Research Institute for Agrobiology and Soil Fertility (AB-DLO), P.O. Box 14, 6700 AA \\ Wageningen the Netherlands \\ ${ }^{2}$ Department of Theoretical Production Ecology, Agricultural University, Bornsesteeg 65, 6708 PD \\ Wageningen the Netherlands
}

\begin{abstract}
A model 'LINTUL-POTATO' is described which bases total dry matter production on light use efficiency of intercepted light by a potato crop. The course of light interception by green leaves initially is temperature-sum dependent and is also steered by influences of daylength and temperature on assimilate partitioning. Dry matter allocation to the foliage, which determines the final length of the growing period, is determined by a daylength and temperature dependent period between emergence and tuber initiation and subsequent partitioning of dry matter to the tubers. Once the tuber daily growth rate equals total crop dry matter accumulation, no more foliage is formed and the crop senesces faster at higher temperatures. The aim of this paper is to explain effects of temperature and daylength on total tuber production from the effects of these environmental factors on the underlying processes. The relative effect of temperature on rates of emergence, light use efficiency, tuber initiation and tuber growth, and, the effect of daylength on development rate until tuber initiation are represented quantitatively. Potential tuber production at some temperature and daylength regimes is calculated exploratively and compared with results from the literature. The model can be used to simulate tuber dry matter production in specific environments and to select cultivars for such environments with suitable temperature and daylength reactions on tuber initiation and dry matter partitioning so as to maximise yields.
\end{abstract}

\section{Introduction}

The model LINTUL-POTATO is described in this paper: This model simulates the Light INTerception and Utilisation, temperature and daylength reactions of POTATO crops grown in different climates. The model is based on the light interception and utilisation model described by Spitters (1987) and Spitters and Schapendonk (1990) and adds temperature and daylength relations. A number of models simulating development and yield of potato have been described, which all perform relatively well under temperate long day conditions (Kabat et al. 1994). Such models, however, do not perform well in (sub)tropical conditions. In such climates, high temperatures during part of the year in lowland areas make the period or area unsuitable for potato growth. In addition to high temperatures, the prevailing short days, sometimes shorter than $11 \mathrm{~h}$, also strongly affect the development of the crop, and often lead to inadequate yields (Haverkort 1990). Models developed under tropical conditions (e.g. Haverkort and Harris 1987) cannot be used under temperate conditions for 


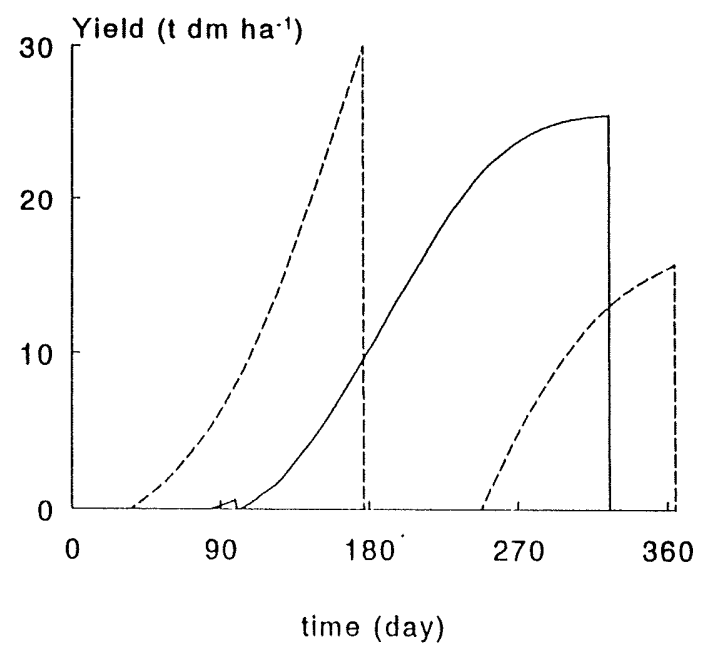

Figure 1. Potential total crop dry matter production in the Netherlands (-) and Tunisia (---).

similar reasons. There is a need for a model that includes crop reactions to temperature and daylength on those crucial processes that determine the length of the growth cycle and therefore the yield of the crop (Kooman 1995; Allen and Scott 1980). Exploration of the yiclding ability of crops in different agroecological zones (Van Keulen and Siol, this volume) can then be carried out more accurately. Such a model may also offer breeders the scope to breed for cultivars which make the most effective use of a given environment described in terms of the yield-defining factors daylength, temperature and solar radiation which cannot be altered by the grower. Growers can affect yield limiting factors through irrigation and fertilisation and they can affect yield reducing factors through crop protection measures. The effect of yield limiting and yield reducing factors on crop growth and development are not included in LINTULPOTATO.

Recently Kooman (1995) analysed the effect of temperature and daylength on growth and development of 8 cullivars in different environments in the Netherlands, Tunisia and Rwanda. Temperature and daylength affected crop production in different ways (see also Struik and Ewing, this volume). Temperature influences dry matter production directly through its influence on daily growth rate. Temperature and daylength influence production indirectly through their influence on development, thus limiting the duration of the growth cycle and yielding ability of the crop. This is illustrated in Figure 1 with long-term temperature and solar radiation data from Tunisia and the Netherlands. One single season in the Netherlands and two distinct growing seasons in Tunisia occur, assuming that no potato crop growth is possible below $2{ }^{\circ} \mathrm{C}$ and above $30^{\circ} \mathrm{C}$ (Van Keulen and Stol, this volume). During winter, minimum daily temperatures in the Netherlands are constantly below $2{ }^{\circ} \mathrm{C}$ and below $28^{\circ} \mathrm{C}$ in summer allowing a single, relatively long growing season of about six months. There is roughly one month period with temperatures that are too low and a three month period with mean daily maximum temperatures 


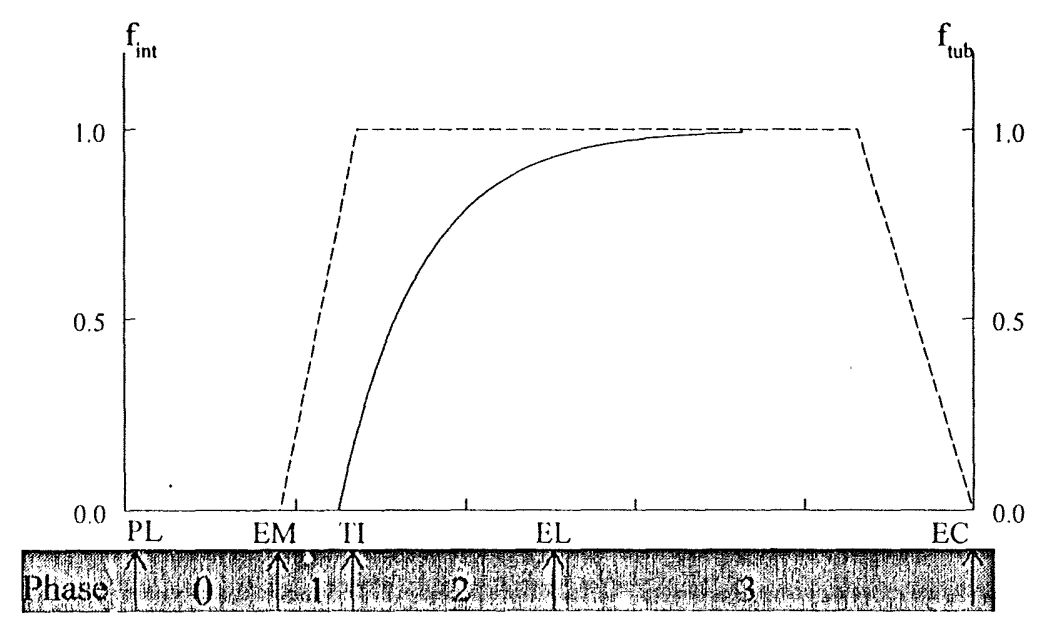

Figure 2. Schematic representation of the fraction of solar radiation intercepted by the crop $\left(f_{\text {int }}\right)$ and the fraction of the daily assimilate that is partitioned to the tubers ( $\left.f_{t u b}\right)$ from planting (PL) to emergence (EM), the start of tuber growth (Tl), the moment that $f_{\text {tub }}$ reaches the value of 0.9 (EL) until the end of crop growth (EC).

above $28^{\circ} \mathrm{C}$, leading to two annual seasons suitable for potato production. With a potential light use efficiency of $2.5 \mathrm{~g} \mathrm{MJ}^{-1}$ based on PAR. Figure 1 illustrates that potential dry matter production in the Tunisian spring is higher than in the temperate summer, that such a dry matter production can be achieved in much less time and that, in the Mediterranean area, potential yields in the autumn season are about half those in the spring season as was found by Fahem and Haverkort (1988). LINTUL-POTATO simulates potential dry matter production in different environments through the relative effect of temperature on rates of emergence, light use efficiency, tuber initiation and tuber growth. Moreover, the effect of daylength on development rate until tuber initiation is quantitatively represented and potential tuber dry matter production is calculated exploratively under some regimes of temperature and daylength.

An analysis of the system of tuber yield formation enables an approach that may be used in areas with widely varying temperature and daylength regimes. Total crop dry matter production is determined by the length of the growth cycle which is divided into four phases each starting and ending by a characteristic stage of development. Phase 0 starts at planting and ends at emergence. Phase 1, when only foliar growth takes place, is from emergence to tuber initiation. Phase 2 is from tuber initiation until the end of leaf growth (defined as the moment when $90 \%$ of the assimilates which are produced daily, are partitioned to the tubers). In this Phase 2 there is competition for assimilates between tuber and foliage. Phase 3, finally, is from the end of leaf growth until the end of crop growth. In Phase 3 all assimilates are partitioned to the tubers. The development of radiation interception and of the daily partitioning of dry matter to the tubers is represented schematically in Figure 2. The system is conveniently divided into the four phases, each with its own key processes described by variables and parameters with values depending on temperature and/or daylength: 
- Phase 0 between planting and emergence (when $50 \%$ of the plants have emerged) the duration of which is determined by the sprout growth rate which depends on temperature;

- Phase 1 between emergence and tuber initiation (also defined as the start of tuber growth) the duration of which depends on the development rate until tuber initiation. In the Phases 1 through 3 the crop growth rate is calculated with the using foliar expansion rate, while the light use efficiency determines the total amount of dry matter produced;

- Phase 2 between tuber initiation and the moment when $90 \%$ of the daily acquired assimilates are partitioned to the tubers. This value is arbitrarily chosen as $100 \%$ partitioning is only reached asymptotically and, as such, cannot be determined precisely. The length of Phase 2 depends on the relative tuber growth rate which determines partitioning of dry matter between the tubers and the rest of the plant;

- Phase 3 lasts until the end of crop growth. The length of the period of Phase 3 is determined by the leaf senescence rate.

LINTUL-POTATO explains the effect of temperature and daylength on final tuber dry matter production through the quantification and integration of temperature and daylength effects on the major growth and development processes described in the Phases $0-3$. The model is also aimed at simulating tuber dry matter production in specific environments and to select cultivars for such environments with suitable temperature and daylength reactions on tuber initiation and dry matter partitioning to maximise yields.

\section{Temperature and daylength relations in LINTUL-POTATO}

\section{Phase 0}

Rate of emergence: temperature relations. Under temperate conditions with low temperatures limiting potato growth in spring, the date of emergence may be calculated from planting depth, initial sprout length, soil temperature (often not available so in LINTUL-POTATO we use the mean daily air temperature) and the sprout growth rate of $1 \mathrm{~mm}$ per ${ }^{\circ} \mathrm{Cd}$ above a base temperature of $2{ }^{\circ} \mathrm{C}$ (MacKerron and Waister 1985). Daylength does not influence the sprout growth rate. At sub-optimal temperatures, whether low (Klemke and Moll 1990) or high (Manrique and Hodges 1989; Midmore 1984; 1988; Van der Zaag et al. 1986) sprout growth rate is reduced. Figure 3a shows the relative effect of temperature on the sprout growth rate compounded from the data collected by these authors: at a relative rate of 1.0 , the sprout growth rate is $1 \mathrm{~mm}$ per ${ }^{\circ} \mathrm{Cd}$.

\section{Phase 1}

Rate of foliar expansion: relation to daylength. Daylength is reported to influence above ground behaviour of potato plants and crops. Menzel (1985a), 

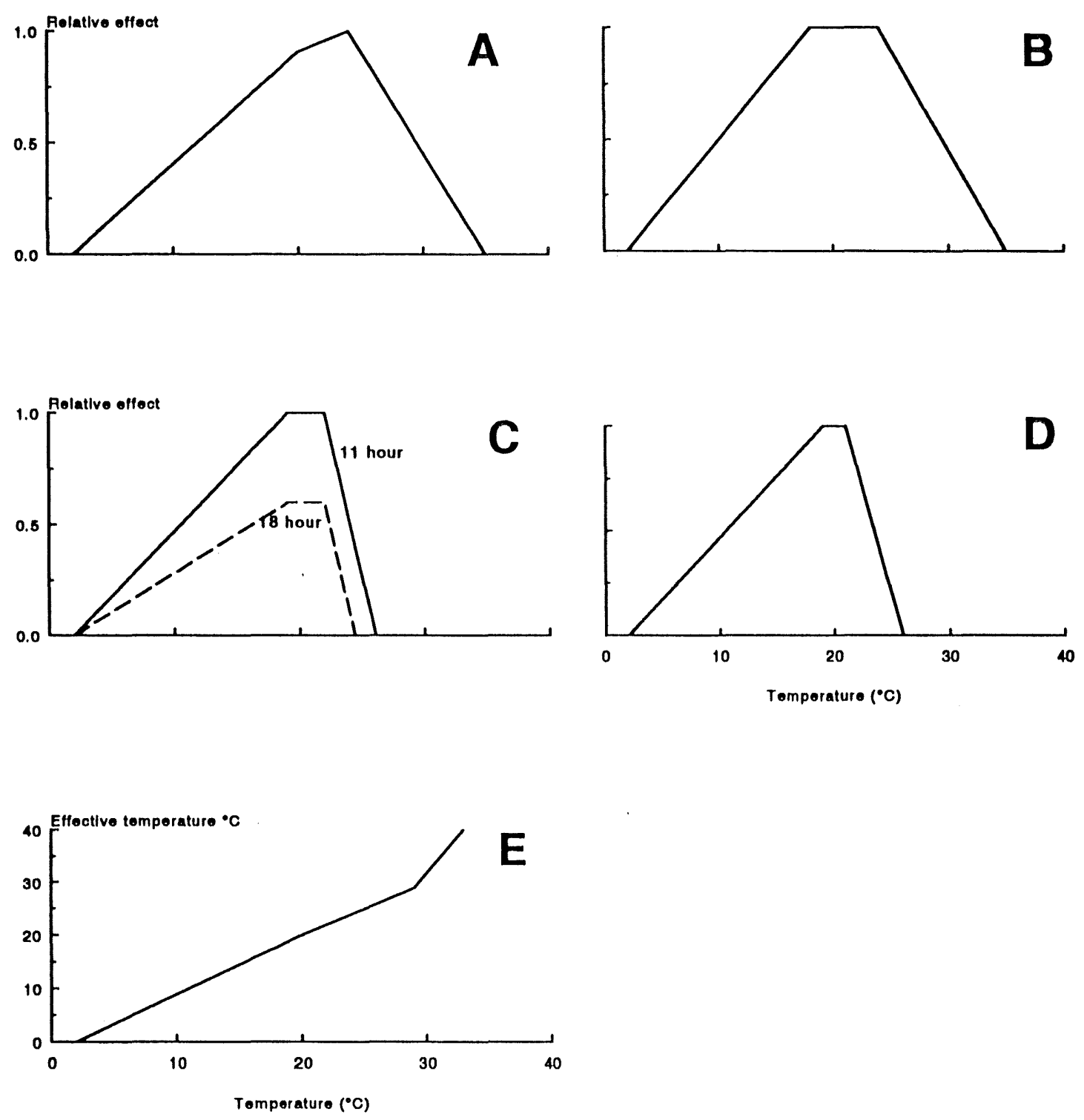

Figure 3. The relative effect of temperature in LINTUL-POTATO on the rates of sprout growth (A), light use efficiency (B), tuber initiation $(\mathrm{C},-$ at $11 \mathrm{~h}$ and --- at $18 \mathrm{~h}$ daylength) and tuber growth (D), and leaf senescence (E).

Ewing and Struik (1992) and Lorenzen and Ewing (1990) reported that short days reduce stem length, branching and weight, the number and weight of leaves and to increase the size of the leaflets and the leaf/stem weight ratio. Haverkort (1990) showed that shorter days reduce the vegetative growth and lead to earlier crop senescence. These observations agree with those of Demagante and Van der Zaag (1988) who observed that lengthening the photoperiod from 11.5 to 16 $\mathrm{h}$ increased branching, flowering and secondary growth. At the crop level, no clear influence on light interception and leaf growth was found by Kooman (1995) between the various climates and cultivars tested. Since the final maximum amount of foliage differed at the various locations, It can be 
concluded that the observations result from a shift in tuber initiation: shorter days increase the tuber initiation rate, thus reducing the length of Phase 1 in Figure 2 and bringing forward Phases 2 and 3 leading to an earlier crop. LINTUL-POTATO, therefore, has no relation linking foliar development to daylength.

Rate of foliar expansion: relation to temperature. Marinus and Bodlaender (1975) observed that foliar growth increased with temperature at low temperatures and Midmore (1984) and Van der Zaag et al. (1986) observed that foliar growth decreased with temperature at high temperatures. MacKerron and Waister (1985) linearly correlated leaf expansion from emergence to temperature above a base temperature of $2.4^{\circ} \mathrm{C}$, Spitters (1987) and Spitters and Schapendonk (1990) used a similar approach with a base temperature of $2^{\circ} \mathrm{C}$. Often minimum $\left(0-7^{\circ} \mathrm{C}\right)$, optimum $\left(20-28^{\circ} \mathrm{C}\right)$ and maximum temperatures for leaf growth have been recorded (e.g. Borah and Milthorpe 1962; Benoit et al. 1983; $\mathrm{Ng}$ and Loomis 1984; Manrique 1992). Maximum temperatures for leaf expansion have been reported as $30^{\circ} \mathrm{C}$ by Ingram and McCloud (1984), $40^{\circ} \mathrm{C}$ by $\mathrm{Ng}$ and Loomis (1984) and $35^{\circ} \mathrm{C}$ by Benoit et al. (1983). We conclude from these literature data that at temperatures below $24^{\circ} \mathrm{C}$ foliar expansion is linearly correlated to temperature and that it is zero again at $35^{\circ} \mathrm{C}$, as such it is simulated in LINTUL-POTATO with optimum rate shown in Table 2.

Development rate until tuber initiation: relation to daylength. Shorter days have been reported to increase the development rate until tuber initiation defined as the inverse of the number of days between emergence and the start of tuber growth. Some authors (e.g. Regel and Sands 1983) reported the existence of a 'critical photoperiod' $14.1 \mathrm{~h}$ for cv. Sebago and $15.5 \mathrm{~h}$ for cv. Kennebec above which tuber formation is retarded. Others (e.g. Lorenzen and Ewing 1990; Struik et al. 1988) reported that a shift from long $(16-18 \mathrm{~h})$ to short $(10-12)$ days increased the development rate until tuber initiation and that short days compared to long days lead to earlier tuber initiation (Snyder and Ewing 1989; Wolf et al. 1990; Ewing and Struik 1992). This was confirmed under field conditions by Kooman (1995) who reported a negative relation between development rate until tuber initiation and the photoperiod prevailing at emergence of the crop. The relative effect of daylength (example of $11 \mathrm{~h}$ and 17 h) on development rate until tuber initiation as it is included in LINTULPOTATO is shown in Figure $3 \mathrm{~d}$ with optimum rate shown in Table 2.

Development rate until tuber initiation: relation to temperature. Under temperate conditions higher temperatures increase the tuberisation rate (Menzel 1983; Hay and Allen 1978) so that thermal time from planting with a base temperature of $0{ }^{\circ} \mathrm{C}$ describes the tuberisation rate well (Jefferies and MacKerron 1987). There is, however, an optimum as many reports on the relation between tuber initiation and temperature concern the observation that high temperatures retard tuber initiation (under tropical conditions) (Sands et 
al. 1979; Manrique and Hodges 1989; Midmore 1984; 1992; Struik et al. 1989a,b; Reynolds and Ewing 1989). Minimum $\left(0-7^{\circ} \mathrm{C}\right)$, optimum $\left(15-20^{\circ} \mathrm{C}\right)$ and maximum $\left(25-30^{\circ} \mathrm{C}\right)$ temperatures for tuber initiation rates have been reported by Borah and Milthorpe (1962), Sale (1979), Manrique and Hodges (1989) and by Ingram and McCloud (1984). The effect of photoperiod was found by Struik and Ewing (1992) to be more pronounced at higher temperatures. This was corroborated by Kooman (1995), who found a decrease of the length of the period of Phase 1 between emergence and tuber initiation (i.e. increased development rate until tuber initiation) at temperatures between 10 and $21^{\circ} \mathrm{C}$. Depending on cultivar and location, this period lasted between 8 and 40 days. These observations allow us to simulate the relative effect of temperature on development rate until tuber initiation in LINTUL-POTATO as shown in Figure 3d with an optimum rate as given in Table 2.

\section{Phase 2}

Tuber growth rate: daylength relation. Photoperiod has been reported to have an influence on the amount of dry matter allocated to the tuber after tuber initiation. Experimental results are often interpreted as 'short days favouring the partitioning of dry matter to the tubers' (e.g. Lorenzen and Ewing 1990; Ewing and Struik 1992; Menzel 1985b; Haynes et al. 1988). A shorter duration of Phase 2 under short days than under long days was found by Kooman (1995). He attributed this to an earlier tuber initiation (Phase 1) leading to higher tuber growth rates (not relative tuber growth rates) early in the season. This finding agrees with Wheeler and Tibbits (1987) as they reported similar dry matter allocation of tubers growing at 12 and 24 h daylength. No effect of daylength on tuber growth rate is included in LINTUL-POTATO.

Tuber growth rate: temperature relation. In LINTUL-POTATO, the relative tuber growth rate is only dependent on temperature. As with the development rate until tuber initiation, there are reports on the decrease of tuber growth rate at high temperatures leading to a shift in assimilate allocation from the tubers to the foliage (e.g. Krauss and Marschner 1984;, Menzel 1985b; Epstein 1966; Randeni and Caesar 1986; Midmore 1992). As with development rate until tuber initiation, so minimum $\left(0-4.4^{\circ} \mathrm{C}\right)$, optimum $\left(15-22^{\circ} \mathrm{C}\right)$ and maximum $(25-35$ ${ }^{\circ} \mathrm{C}$ ) temperatures have been observed for tuber growth rates (Borah and Milthorpe 1962; Yandell et al. 1988; Manrique 1992; Hartz and Moore 1978; Spitters 1987; Ingram and McCloud 1984) The last, for instance assumed a maximum tuber growth rate between 16 and $24^{\circ} \mathrm{C}$. At 10 and $30^{\circ} \mathrm{C}$ the growth rate was half of that at optimum and at 4 and $35^{\circ} \mathrm{C}$ the tuber growth rates were 0 . Kooman (1995) reported a shorter duration of Phase 2 with increasing temperature, up to the temperature of about $22^{\circ} \mathrm{C}$. Based on these observations we simulate the relative effect of temperature on the relative tuber growth rate in LINTUL-POTATO as shown in Figure $3 \mathrm{e}$ with maximum rate shown in Table 2. 


\section{Phase 3}

Crop senescence rate: relation to temperature. Crop senescence takes place earlier at higher temperatures (Menzel 1985a) although the total length of the growing period may last longer because the total period of leaf formation may increase (Marinus and Bodlaender 1975). Leaf longevity has been recorded to last between 1440 and $1760{ }^{\circ} \mathrm{Cd}$ (Vos and Oyarzun 1987). A leaf formed was estimated to be functional for about 23 days at $20^{\circ} \mathrm{C}$ and 12 days at $30^{\circ} \mathrm{C}$ by Ingram and McCloud (1984) under conditions in Florida. Kooman (1995) estimated leaf longevity under conditions in the Netherlands to be between 1000 and $1700{ }^{\circ} \mathrm{Cd}$, depending on cultivar. In LINTUL-POTATO we incorporated the effect of temperature as shown in Figure $3 \mathrm{~b}$ : doubling the effective temperature for leaf senescence rate from $30{ }^{\circ} \mathrm{C}$ onward, adequately accommodates the reductions observed in foliar development at high temperatures.

\section{Phases 1, 2 and 3}

Light use efficiency: temperature relations. Daily crop growth per unit leaf area or unit soil covered by green foliage results from photosynthesis and respiration both of which are temperature dependent. Minimum (between 0 and $7^{\circ} \mathrm{C}$ ), optimum $\left(16-25^{\circ} \mathrm{C}\right)$ and maximum $\left(40^{\circ} \mathrm{C}\right)$ temperatures for photosynthesis in potato crops have been reported by Ku et al. (1977), Dwelle et al. (1981), Dwelle (1985), $\mathrm{Ng}$ and Loomis (1984), Manrique (1992), Midmore (1992) and Hammes and Jager (1990). The highest total daily crop growth is reported between temperatures of 15 and $23^{\circ} \mathrm{C}$ (Ben Kheder and Ewing 1985; Nishibe et al. 1988; Haverkort 1990). A strong increase in respiration with temperature, especially above about $25^{\circ} \mathrm{C}$ (e.g. Sale 1974; $\mathrm{Ng}$ and Loomis 1984; Midmore 1992) could contribute to the difference between optimum for photosynthesis and for crop growth rate and to the often observed reduction of the light use efficiency at increasing temperatures. Haverkort and Harris (1987) and Manrique et al. (1991) presented linear correlations between the observed reduction of crop light use efficiencies and temperatures above $20^{\circ} \mathrm{C}$, with a slope of about -0.02 per ${ }^{\circ} \mathrm{C}$. Combining the various evidence, in LINTUL-POTATO we simulate the effect of temperature on the light use efficiency as shown in Figure $3 \mathrm{c}$ with the optimum rate of $2.5 \mathrm{~g} \mathrm{MJ}^{-1}$. We assume that there is no influence of daylength on light use efficiency. Rather than using a negative linear relation between light use efficiency and total daily radiation to accommodate for light saturation of the canopy, LINTUL-POTATO only uses daily values up to a maximum of $12 \mathrm{MJ}$ $\mathrm{m}^{-2}$ (Kooman 1995), disregarding radiation in excess of this value. 
Table 1. Sequence of equations describing development and growth in LINTUL-POTATO (' $\mathrm{V}$ ` $=$ if)

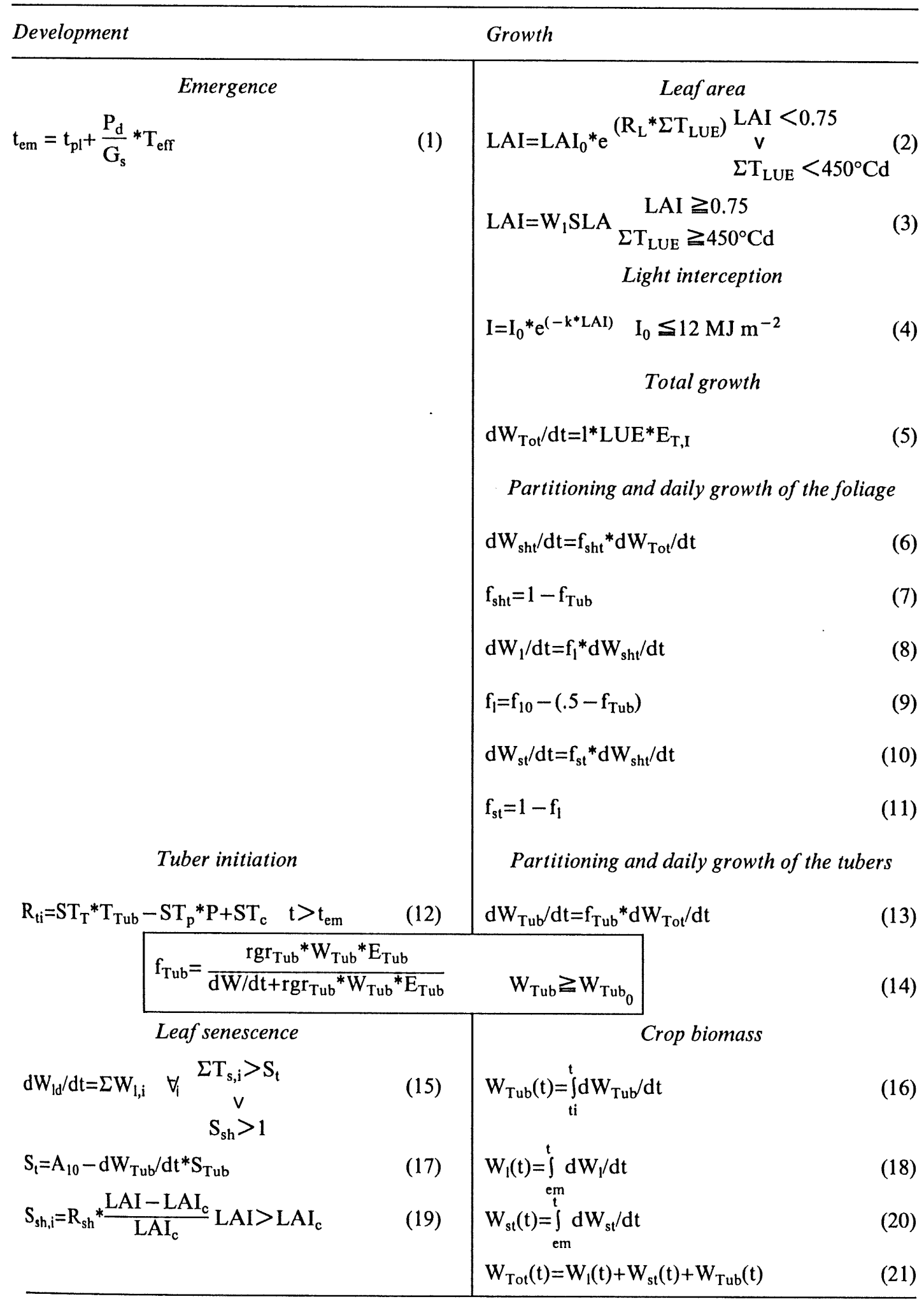


Table 2. List of acronyms and equations used in LINTUL-POTATO

\begin{tabular}{|c|c|c|c|}
\hline Acronym & Meaning and source & Value & Unit \\
\hline$A_{10}$ & Initial longevity of a daily leaf class (Kooman 1995) & 1000 & ${ }^{\circ} \mathrm{Cd}$ \\
\hline day & Julian day & Input & $\mathrm{d}$ \\
\hline$E_{T, l}$ & Relative effect of temperature on light use efficiency & Figure $3 b$ & - \\
\hline$E_{T, s}$ & $\begin{array}{l}\text { Relative effect of temperature on rate of leaf } \\
\text { senescence }\end{array}$ & Figure $3 \mathrm{e}$ & - \\
\hline$E_{T, t i}$ & $\begin{array}{l}\text { Relative effect of temperature on development rate } \\
\text { until tuber initiation }\end{array}$ & Figure $3 c$ & - \\
\hline$E_{T, t}$ & $\begin{array}{l}\text { Relative effect of temperature on relative tuber } \\
\text { growth rate }\end{array}$ & Figure $3 \mathrm{~d}$ & \\
\hline$E_{T, e}$ & Relative effect of temperature on sprout growth rate & Figure $3 a$ & \\
\hline$f_{l}$ & $\begin{array}{l}\text { Fraction of daily shoot dry matter production } \\
\text { allocated to the leaves }\end{array}$ & Output & - \\
\hline$f_{10}$ & $\begin{array}{l}\text { Initial fraction of daily shoot dry matter production } \\
\text { allocated to the leaves (Kooman 1995) }\end{array}$ & 0.8 & - \\
\hline$f_{\text {sht }}$ & $\begin{array}{l}\text { Fraction of daily total dry matter production } \\
\text { allocated to the foliage }\end{array}$ & Output & - \\
\hline$f_{s t}$ & $\begin{array}{l}\text { Fraction of daily shoot dry matter production } \\
\text { allocated to the stems }\end{array}$ & Output & - \\
\hline$f_{t u b}$ & $\begin{array}{l}\text { Fraction of daily total dry matter production } \\
\text { allocated to the tubers }\end{array}$ & Output & - \\
\hline$G_{s}$ & Sprout growth rate (MacKerron and Waister, 1985) & 1 & $\mathrm{~mm}^{\circ} \mathrm{Cd}^{-1}$ \\
\hline$i$ & Index daily leaf class & Index & $\mathrm{d}$ \\
\hline$I$ & Intercepted PAR & Output & $\mathrm{MJ} \mathrm{m}^{-2}$ \\
\hline $\begin{array}{l}I_{0} \\
k\end{array}$ & Total incident PAR & Input & $\mathrm{MJ} \mathrm{m}^{-2}$ \\
\hline$k$ & $\begin{array}{l}\text { Extinction coefficient (Spitters and Schapendonk } \\
\text { 1990) }\end{array}$ & & \\
\hline$L A I$ & $\begin{array}{l}\text { 1990) } \\
\text { Leaf Area Index }\end{array}$ & 1 & $-2-2$ \\
\hline$L A I_{c}$ & $\begin{array}{l}\text { Leaf Area Index } \\
\text { Critical leaf area Index (Kooman 1995) }\end{array}$ & Output & $\begin{array}{l}\mathrm{m}^{2} \mathrm{~m}^{-2} \\
\mathrm{~m}^{2} \mathrm{~m}^{-2}\end{array}$ \\
\hline$L A I_{0}$ & $\begin{array}{l}\text { Critical leaf area Index (Kooman 1995) } \\
\text { Initial leaf area Index (Spitters and Schapendonk }\end{array}$ & 6.0 & $\mathrm{~m}^{2} \mathrm{~m}^{-2}$ \\
\hline & 1990) & $\begin{array}{l}0.0155 \\
\times \mathrm{NPL}\end{array}$ & $\mathrm{m}^{2} \mathrm{~m}^{-2}$ \\
\hline $\begin{array}{l}L U E \\
N P L\end{array}$ & Light use efficiency (Kooman 1995) & 2.5 & $\mathrm{~g} \mathrm{MJ}^{-1}$ \\
\hline $\begin{array}{l}N P L \\
P\end{array}$ & number of plants & 4.4 & $\# \mathrm{~m}^{-1}$ \\
\hline $\begin{array}{l}P \\
P_{d}\end{array}$ & Photoperiod & Input & $\mathrm{h}$ \\
\hline $\begin{array}{l}P_{d} \\
r g r_{t u b}\end{array}$ & Planting depth & Input & $\mathrm{cm}$ \\
\hline$r g r_{t u b}$ & $\begin{array}{l}\text { Relative growth rate of tubers (Ingram and McCloud } \\
\text { 1984) }\end{array}$ & 0.37 & $\mathrm{~g} \mathrm{~g}^{-1} \mathrm{~d}^{-1}$ \\
\hline$R_{l}$ & $\begin{array}{l}\text { Relative increase rate leaf area (Spitters and } \\
\text { Schapendonk 1990) }\end{array}$ & 0.012 & $\mathrm{~m}^{2} \mathrm{~m}^{-2} \mathrm{~d}^{-1}$ \\
\hline$R_{\text {sh }}$ & Senescence rate due to shade (Kooman 1995) & 0.1 & $d^{-1}$ \\
\hline$R_{t i}$ & Development rate until tuber initiation & Calculated & \\
\hline$S L A$ & Specific leaf area (Van Oijen et al. 1995) & 0.0023 & $\mathrm{~m}^{2} \mathrm{~g}^{-1}$ \\
\hline $\begin{array}{l}S_{t} \\
S_{\text {s }}\end{array}$ & Leaf longevity & Output & \\
\hline $\begin{array}{l}S_{s h} \\
S T_{C}\end{array}$ & Senescence due to shading & Output & \\
\hline$S T_{C}$ & $\begin{array}{l}\text { Constant in calculating start tuber growth } \\
\text { (Kooman 1995) }\end{array}$ & 0.119 & \\
\hline$S T_{P}$ & $\begin{array}{l}\text { Daylength parameter calculating start tuber growth } \\
\text { (Kooman 1995) }\end{array}$ & $6.210^{-4}$ & $\mathrm{~h}^{-1}$ \\
\hline
\end{tabular}


Table 2. Continued.

\begin{tabular}{llll}
\hline Acronym & Meaning and source & Value & Unit \\
\hline$t$ & time & Input & $\mathrm{d}$ \\
$t_{e m}$ & Day of emergence & Output & $\mathrm{d}$ \\
$t_{p l}$ & Day of planting & Input & $\mathrm{d}$ \\
$t_{s t}$ & Day of start tuber growth & Output & $\mathrm{d}$ \\
$T$ & Daily average temperature & Input & ${ }^{\circ} \mathrm{C}$ \\
$T_{0}$ & Base temperature for potato growth (Spitters and & & \\
& Schapendonk 1990) & 2 & ${ }^{\circ} \mathrm{C}$ \\
$T_{e f f}$ & Effective temperature for potato growth & Output & ${ }^{\circ} \mathrm{C}$ \\
$T_{l u e}$ & Effective temperature for total growth & Output & ${ }^{\circ} \mathrm{C}$ \\
$T_{t u b}$ & Effective temperature for tuber growth & Output & ${ }^{\circ} \mathrm{C}$ \\
$T_{s}$ & Effective temperature for senescence of foliage & Output & ${ }^{\circ} \mathrm{C}$ \\
$W_{l}$ & Weight of green leaf dry matter & Output & $\mathrm{kg} \mathrm{m}^{-2}$ \\
$W_{l d}$ & Weight of dead leaf dry matter & Output & $\mathrm{kg} \mathrm{m}^{-2}$ \\
$W_{s h t}$ & Weight of shoot dry matter & Output & $\mathrm{kg} \mathrm{m}^{-2}$ \\
$W_{s t}$ & Weight of stem dry matter & Output & $\mathrm{kg} \mathrm{m}^{-2}$ \\
$W_{T o t}$ & Weight of total dry matter & Output & $\mathrm{kg} \mathrm{m}^{-2}$ \\
$W_{t u b}$ & Weight of tuber dry matter & Output & $\mathrm{kg} \mathrm{m}^{-2}$ \\
\hline
\end{tabular}

\section{Model structure of LINTUL-POTATO}

LINTUL-POTATO is partly based on dry matter accumulation with allocation governed by a dominant tuber sink (Spitters 1990; Kooman 1995; Spitters and Schapendonk 1990) using quantitative relationships from Moorby (1968), Sale (1974) and Gawronska et al. (1984). Part of the model was described by Kooman (1995) and the complete set of equations is given here in Table 1 with Table 2 describing the meaning of the acronyms and the (initial or optimum) values of the variables and parameters used.

The development of the crop starts at planting. The planting depth and the effective temperature (Figure 3a) determine the time between planting and emergence (Eq. 1). In the early stages of crop growth, temperatures rather than assimilates determine leaf area expansion and is therefore modeled according to Eq. 2. When the temperature sum from emergence exceeds $450^{\circ} \mathrm{Cd}$ or the leaf area index exceeds 0.75 , the increase of leaf area is determined by the availability of assimilates and is calculated as the product of leaf dry weight and specific leaf area (Eq. 3 from Spitters 1990; Spitters and Schapendonk 1990). Leaves are divided into classes based on the day in which the leaves are formed in. These daily classes senesce when the temperature sum integrated by the class exceeds the leaf longevity or when the leaf area above the leaf layer is such that shading is too strong (Eqs. 15 and 19). The leaf longevity is also influenced by tuber growth such that fast growing tubers reduce leaf longevity (Eq. 17). Crop growth ceases when the leaves in the latest class have senesced. 
photosynthetically active radiation intercepted by the canopy calculated from the leaf area index (LAI, Eqs. 3 and 4) and its conversion efficiency for dry matter production (Eq. 5, Figure 3c). The growth of the different plant parts is calculated from the total dry matter production and the partition coefficients to the parts (Eqs. 6-11, 13 and 14). To obtain the cumulative amount of dry matter produced, the daily growth is integrated over the growing period (Eqs. 16-21).

After emergence the development rate until tuber initiation is determined by temperature and daylength (Eq. 12, Figure 3d). Assimilate allocation to the tubers receives priority after tuber initiation: TI in Figure 2. Initially, tuber growth is sink-limited and results from the product of the relative growth rate and the tuber weight. Thereafter, tubers become an increasing sink as they become larger, however, in this phase the source is not large enough to deliver all assimilates needed to maintain simultaneously exponential tuber growth and leaf growth, resulting in an increasing part of the daily assimilates allocated to the tubers. Finally, tuber growth becomes source-limited and all assimilates produced go to the tubers. This course of tuber growth is described by Eq. 17 and the relative effect of temperature on the relative tuber growth rate is given in Figure 3e. Assimilates not allocated to the tubers are allocated to the shoot and divided between the leaves and stems (Eqs. 7-11). Root biomass is not taken into account as precise experimental measurements of roots in the field experiments are rare.

\section{Simulation of temperature and daylength responses with LINTUL-POTATO}

LINTUL-POTATO, as it is presented here, can be used for two main purposes.

Firstly, the values of variables and parameters in LINTUL-POTATO as they are presented here (Figure 3, Table 1) are mean values taken from literature and, where needed, adjusted by data given by Kooman (1995). Data presented by Kooman (1995) on parameter values of 8 Solanum tuberosum cultivars varying in earliness and grown in the Netherlands, Tunisia (winter, spring and autumn seasons) and $\mathrm{R}$ wanda ( 2 altitudes) give a range of values for Dutch cultivars that are currently grown. Given a specific environment of temperature and daylength, desired cultivar characteristics for responses to these (especially on tuber initiation and tuber growth rates) can be evaluated by the model to calculate the potential tuber production in such an environment.

Secondly, the estimation of potential tuber yields in various regions (Figure 1) can be improved considerably by the use of a dynamic dry matter allocation as in the model, rather than assuming a fixed harvest index of about 0.75 at crop senescence. LINTUL-POTATO takes into account prohibitive low or high temperatures for sprout growth before emergence in Phase 0 (Figure 2). The parameters related to the tuber initiation rate (Phase 1), which is temperature and daylength dependent, can be given values such that the length of Phases 2 and 3 are sufficiently long so that the total length of the growing season fits in the period suitable for potato growh, between 2 an $30^{\circ} \mathrm{C}$. 


\section{1 hours}

\section{7 hours}
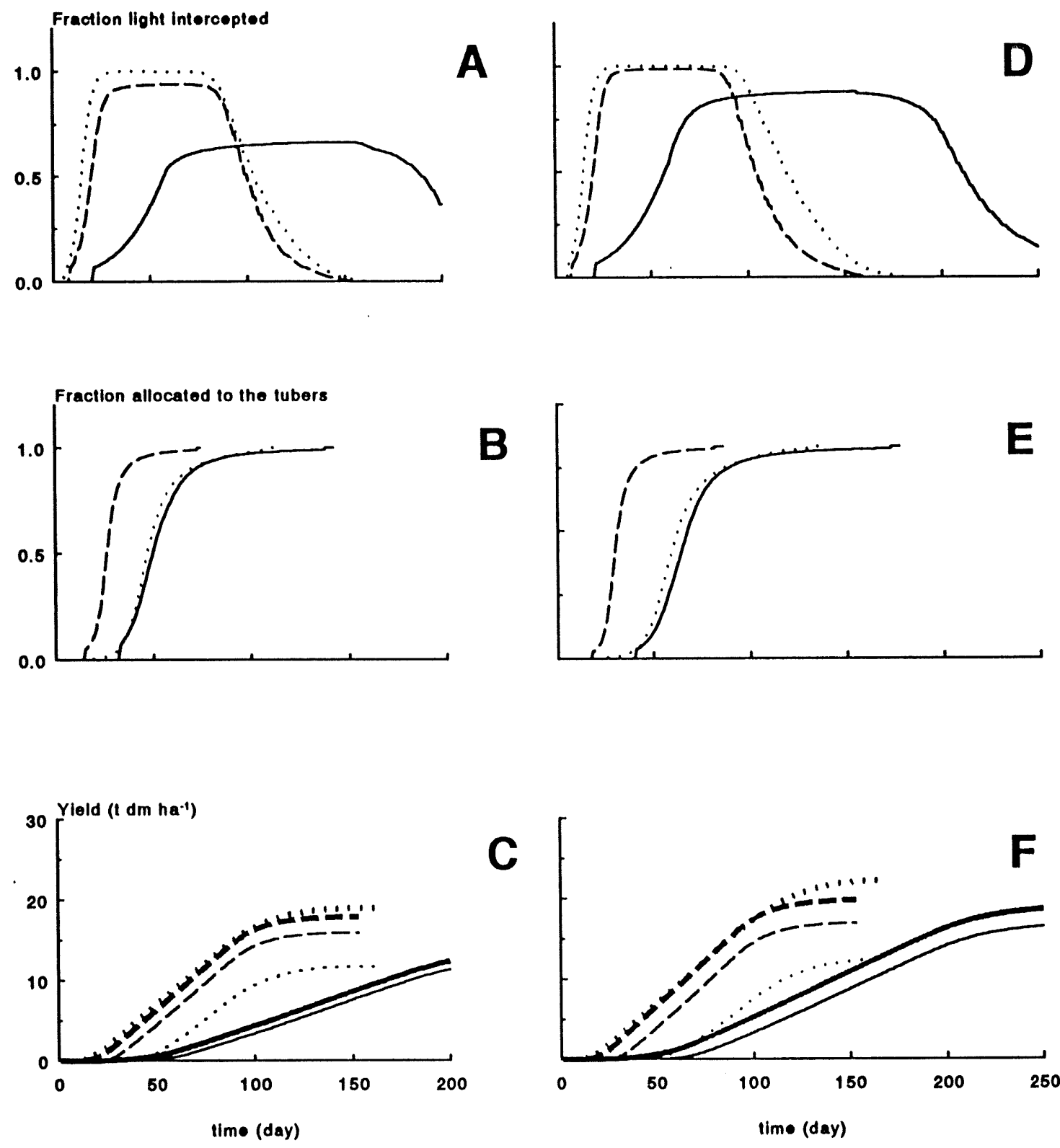

Figure 4. Simulated development of light interception (A,D), dry matter partitioning to the tubers $(\mathrm{B}, \mathrm{E})$, total (thick) and tuber dry matter production (thin) (C,F) at $10(-), 17(---)$ and $25^{\circ} \mathrm{C}(\ldots)$ and at daylengths of $11(\mathrm{~A}, \mathrm{~B}, \mathrm{C})$ and $17 \mathrm{~h}(\mathrm{D}, \mathrm{E}, \mathrm{F})$.

The effect of different temperatures and daylengths on the length of the growing season, expressed as the period when the ground is (partially) covered by green foliage is shown in Figure 4 together with the development of the proportion of light interception, the fractional daily assimilates partitioning to 
the tubers, and tuber dry matter production, using the standard values of LINTUL-POTATO as presented in Table 1 . and assuming a daily solar radiation level of $9 \mathrm{MJ} \mathrm{m}^{-2}$ throughout the season. The figure shows the effect of growing potatoes at mean daily temperatures of 10,17 and $25^{\circ} \mathrm{C}$ throughout the growing season at daylengths at emergence of 11 and $17 \mathrm{~h}$.

Table 3. Simulated end of Phases 1,2 and 3 (Days After Planting, DAP), total and tuber yield at the end of the growth cycle

\begin{tabular}{|c|c|c|c|c|c|c|c|c|c|c|}
\hline \multirow[t]{3}{*}{ Temperature } & \multirow{2}{*}{\multicolumn{2}{|c|}{$\begin{array}{l}\text { Phase } 1 \\
\text { (D^P) } \\
\text { Photoperiod }\end{array}$}} & \multirow{2}{*}{\multicolumn{2}{|c|}{$\begin{array}{l}\text { Phase } 2 \\
\text { (DAP) } \\
\text { Photoperiod }\end{array}$}} & \multirow{2}{*}{\multicolumn{2}{|c|}{$\begin{array}{l}\text { Phase } 3 \\
\text { (DAP) } \\
\text { Photoperiod }\end{array}$}} & \multirow{2}{*}{\multicolumn{2}{|c|}{$\begin{array}{l}\text { Total yield } \\
\left(\mathrm{t} \mathrm{ha}^{-1}\right)\end{array}$}} & \multirow{2}{*}{\multicolumn{2}{|c|}{$\begin{array}{l}\text { Tuber yield } \\
\left(t_{\text {ha }}{ }^{-1}\right) \\
\text { Photoperiod }\end{array}$}} \\
\hline & & & & & & & & & & \\
\hline & $11 \mathrm{~h}$ & $17 \mathrm{~h}$ & 111 & $17 \mathrm{~h}$ & $11 \mathrm{~h}$ & $17 \mathrm{~h}$ & $11 \mathrm{~h}$ & $17 \mathrm{~h}$ & $11 \mathrm{~h}$ & $17 \mathrm{~h}$ \\
\hline $10^{\circ} \mathrm{C}$ & 33 & 41 & 72 & 89 & 274 & 300 & 13.3 & 19.0 & 12.3 & 16.9 \\
\hline $17^{\circ} \mathrm{C}$ & 15 & 18 & 32 & 42 & 153 & 162 & 17.8 & 19.7 & 15.9 & 16.9 \\
\hline $25^{\circ} \mathrm{C}$ & 15 & 23 & 70 & 87 & 162 & 173 & 18.9 & 22.1 & 11.7 & 12.3 \\
\hline
\end{tabular}

At $10{ }^{\circ} \mathrm{C}$ the rates of emergence and initial light interception are low. Emergence takes place on day 21 and the start of tuber growth takes place on day 33 which is too early to enable the crop to reach full ground cover. Ground cover reaches a maximum of about $60 \%$. Because of the subsequent low total growth rate the fraction of dry matter allocated to the tubers increases rapidly and it takes about 40 days from tuber initiation until $90 \%$ of the dry matter is allocated to the tubers (Table 3). The rate of senescence of the crop is low, resulting in a relative long growth cycle of about 270 days. Because of the low ground cover and the low growth rate at $10^{\circ} \mathrm{C}$ the tuber dry matter production is only $12.3 \mathrm{t}$ $\mathrm{ha}^{-1}$. At $17{ }^{\circ} \mathrm{C}$, emergence and initial growth are faster than at $10{ }^{\circ} \mathrm{C}$. Emergence is brought forward by 12 days and the start tuber growth is 18 days earlier. The higher crop grow th rate at $17^{\circ} \mathrm{C}$ allows the crop to reach $95 \%$ ground cover. Both tuber growth rate and leaf senescence rates are higher at $17^{\circ} \mathrm{C}$ than at $10^{\circ} \mathrm{C}$ leading to a reduction in the senescence period to 37 days. The total length of the growth cycle of the crop grown at $17^{\circ} \mathrm{C}$ is 153 days. Due to the high growth rates and the early allocation of dry matter to the tubers, this crop produced $16 \mathrm{t} \mathrm{ha}^{-1}$ tuber dry matter by the end of the growing season. At $25^{\circ} \mathrm{C}$ emergence takes place after 7 days but tuber initiation is not brought forward (see Figure $3 \mathrm{~d}$ ) but takes place two days later than at $17^{\circ} \mathrm{C}$. The initial tuber growth is very slow and, therefore, the end leaf growth (end of Phase 2, Figure 2) is only reached on day 70 . The total growth cycle is as long as at $17^{\circ} \mathrm{C}$. The greater rate of senescence counteracts the effect of increased foliar development because of a reduced fraction of dry matter allocated to the tuber which also explains why tuber dry matter production does not exceed $12 \mathrm{tha}^{-1}$.

Carrying out the simulation for $17 \mathrm{~h}$ (Figure 4D,E,F) rather than for a daylength of $1 \mathrm{~h}$ (Figure $4 \mathrm{~A}, \mathrm{~B}, \mathrm{C}$ ) shows that the teng ths of the gro are 
increased and that a greater amount of light is intercepted. The increased growth cycle resulted from a delay in tuber initiation (Table 3), which delays dry matter allocation to the tubers. The increased growth cycle increased total dry matter production in t ha ${ }^{-1}$ from $13.3\left(\right.$ at $10^{\circ} \mathrm{C}$ ) and $18.9\left(\right.$ at $25^{\circ} \mathrm{C}$ ) at $11 \mathrm{~h}$ daylength to 19.0 and 22.1 at $17 \mathrm{~h}$. The tuber dry matter production increased less than total dry matter production. The increase was largest at $10^{\circ} \mathrm{C}(4.6 \mathrm{t})$ and smallest at $25^{\circ} \mathrm{C}(0.6 \mathrm{t})$.

The model is not yet fully validated here. Comparison with independent data was carried out by Kooman (1995). LINTUL-POTATO simulates the trends in tuber dry matter production and crop behaviour as reported in literature: earlier tuber initiation under short days leads to earlier senescence (Haverkort 1990; Ewing and Struik 1992). At $10^{\circ} \mathrm{C}$ total dry matter production was lower than at $17^{\circ} \mathrm{C}$ which agrees with literature data from $\mathrm{Ng}$ and Loomis (1984), Ingram and McCloud (1984) and Spitters (1990) who reported optimal yields between 15 and $22{ }^{\circ} \mathrm{C}$. Total dry matter differed only slightly between 17 and $25^{\circ} \mathrm{C}$ as was also found by Marinus and Bodlaender (1975) comparing plant performance at 16, 22 and $28^{\circ} \mathrm{C}$. In long days, the growing season is longer at 25 than at $17^{\circ} \mathrm{C}$ but the tuber dry matter production is lower due to reduced harvest indices at higher temperatures (Ben Kheder and Ewing 1985; Manrique 1992).

We also used LINTUL-POTATO to determine the optimum temperature for potato growth at varying daylengths. The range of temperatures tested throughout the growing season varied from 2 to $28^{\circ} \mathrm{C}$ and the simulations were carried out for daylengths of 11,14 and $17 \mathrm{~h}$. The resulting total tuber dry matter production is presented in Figure 5. The highest tuber dry matter production at the $11 \mathrm{~h}$ daylength is achieved at about $17^{\circ} \mathrm{C}$. Longer days (e.g. $17 \mathrm{~h}$ ) broaden the optimum range of temperatures and centre it at about $14^{\circ} \mathrm{C}$.

The range of optimum temperatures for potato production calculated by LINTUL-POTATO shown in Figure 5 includes the optimum temperatures reported in literature: $13{ }^{\circ} \mathrm{C}$ by Spitters $(1987), 14-22{ }^{\circ} \mathrm{C}$ by Ingram and

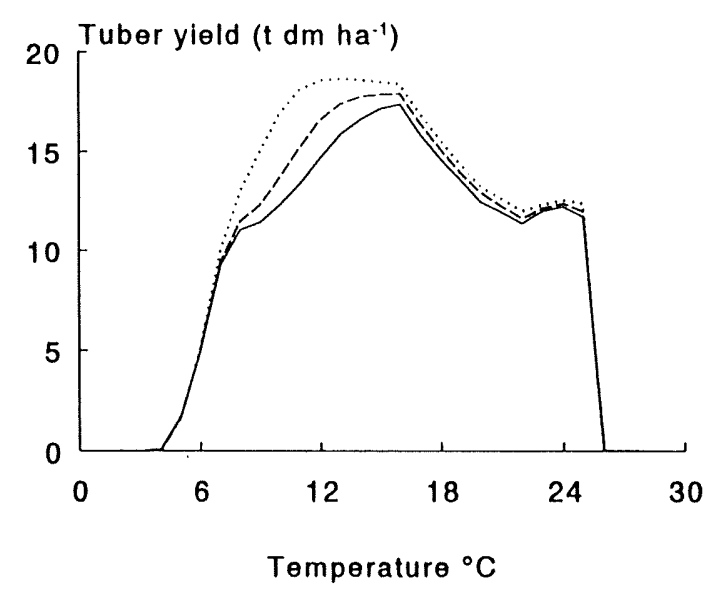

Figure $5:$ Simulated-relation between-tuber-dry=matter-production by=the time-of-crop-senescence versus mean daily temperature throughout the growing season at daylengths of $11(-), 14(---)$ and 
McCloud (1984), $16-24^{\circ} \mathrm{C}$ by $\mathrm{Ng}$ and Loomis (1984), $18^{\circ} \mathrm{C}$ by Borah and Milthorpe (1962), $15-22^{\circ} \mathrm{C}$ by Midmore (1992), $18-20^{\circ} \mathrm{C}$ by Manrique (1992) and $21^{\circ} \mathrm{C}$ by Sands et al. (1979).

The wider range of optimum temperatures in long days than in short days is explained as follows. The optimum crop growth rate is between 18 and $24^{\circ} \mathrm{C}$ (Figure 3B) and is not affected by daylength. Short days bring forward tuber initiation and reduce the total length of the growth cycle and/or the maximum level of light interception, hence total and tuber dry matter production. Longer days at low temperatures however, retard tuber initiation to such an extent (Figure 3C) that it leads to longer growth cycles and/or higher maximum levels of light interception resulting in higher total and tuber production.

The phenomenon of a wider optimum temperature range for growth of the crop in longer days, may well explain the adaptability of potato to a wide range of climates. Besides its short day and low temperature origin, the crop also performs well in ecoregions with higher temperatures such as the Mediterranean area and the continental summer, because the prevailing daylength during the growing season here is longer than in the centre of origin.

Compared to experimental research, LINTUL-POTATO yields more commonly applicable information. In experiments the lateness of a crop is beside daylength, affected by other factors such as cultivar and seed age. The optimum temperature for tuber production, assessed in an experiment, therefore is always specific for that experiment. Which may explain the differences in optimum temperatures reported in literature.

The model LINTUL-POTATO simulated temperature and daylength responses similar to those reported in literature. The concept of dry matter allocation therefore is a valid tool to explain variation in potato production under different climatic conditions. Accurate quantification of the variables for cultivars differing in lateness and comparison of the model with independent data is reported by Kooman (1995).

\section{Acknowledgements}

Critical comments on the manuscript by Dr. M. van Oijen are gratefully acknowledged.

\section{References}

Allen E J, Scott R K (1980) An analysis of growth of the potato crop. Journal of Agricultural Science Cambridge 94:583-606.

Ben Kheder M, Ewing E E (1985) Growth analyses of eleven potato cultivars grown in the greenhouse under long photoperiods with and without heat stress. American Potato Journal 62:537-554.

Benoit G R, Stanley C D, Grant W J, Torrey D B (1983) Potato top growth as influenced by temperatures. American Potato Journal 60:489-501. 
Borah M N, Milthorpe F L (1962) Growth of potato as influenced by temperature. Indian Journal of Plant Physiology 5:53-70.

Demagante A L, Van der Zaag P (1988) The response of potato (Solanum spp.) to photoperiod and light intensity under high temperatures. Potato Research 31 (1):73-83.

Dwelle R B, Kleinkof G E, Steinhorst R K, Pavek J J, Hurley P J (1981) The influence of physiological processes on tuber yield of potato genotypes (Solanum tuberosum L.): stomatal diffusive resistance, stomatal conductance, gross photosynthetic rate, leaf canopy, tissue nutrient levels and tuber enzyme activities. Potato Research 24:33-47.

Dwelle R E (1985) Photosynthesis and photoassimilate partitioning. Pages 35-58 in Li P H (Ed.) Potato Physiology. Academic Press, Orlando, USA.

Epstein E (1966) Effect of soil temperature at different growth stages on growth and development of potato plants. Agronomy Journal 58:169-171.

Ewing E E, Struik P C (1992) Tuber formation in potato: Induction, initiation, and growth. Horticultural Reviews 14:89-198.

Fahem M, Haverkort A J (1988) Comparison of the growth of potato crops grown in autumn and spring in North Africa. Potato Research 31:557-568.

Gawronska H, Dwelle R B, Pavek J J, Rowe P (1984) Partitioning of photoassimilates by four potato clones. Crop Science 24:1031-1036.

Hammes, P S, De Jager J A (1990) Net photosynthetic rate of potato at high temperatures. Potato Research 33:515-520.

Hartz T.K., Moore F.D. (1978) Prediction of potato yields using temperature and insolation data. American Potato Journal 55:431-436.

Haverkort A J (1990) Ecology of potato cropping systems in relation to latitude and altitude. Agricultural Systems 32:251-272.

Haverkort A J, Harris P M (1987) A Model for potato growth and yield under tropical highland conditions. Agricultural and Forest Meteorology 39:271-282.

Hay R K M, Allen E T (1978) Tuber initiation and bulking in the potato (Solanum Tuberosum) under tropical condition: The importance of soil and air temperatures. Tropical Agriculture 55:289-295.

Haynes K, Haynes F L, Swallow W H (1988) Temperature and photoperiod effects on tuber production and specific gravity in diploid potatoes. HortScience 23:562-565.

Ingram K T, McCloud D E (1984) Simulation of potato crop growth and development. Crop Science 24:21-27.

Jefferies R A, Mackerron D K L (1987) Thermal time as a non destructive method of estimating tuber initiation in potatoes. Journal of Agricultural Science Cambridge 108:249-252.

Kabat P, van den Broek B, Marshall B, Vos J ąnd van Keulen H (1995) Modelling and parameterization of the soil - plant - atmosphere system, a comparison of potato growth models. Wageningen Pers, Wageningen, The Netherlands.

Klemke T, Moll A (1990) Model for simulation of potato growth from planting to emergence. Agricultural Systems 32:295-304.

Kooman P L (1995) Yielding ability of potato crops as influenced by temperature and daylength. $\mathrm{Ph} . \mathrm{D}$. Thesis, Wageningen Agricultural University, Wageningen, The Netherlands.

Krauss A, Marschner H (1984) Growth rate and carbohydrate metabolism of potato tubers exposed to high temperatures. Potato Research 27:297-303.

Ku S B, Edwards G E, Tanner C B (1977) Effects of light, carbon dioxide and temperature on photosynthesis, oxygen inhibition of photosynthesis and transpiration in Solanum tuberosum. Plant Physiology 59:868-872.

Lorenzen J H, Ewing E E (1990) Changes in tuberization and assimilate partitioning in Potato (Solanum tuberosum) during the first 18 days of photoperiod treatment. Annals of Botany 66:457-464.

Mackerron D K L, Waister P D (1985) A simple model of potato growth and yield. Part I. Model development and sensitivity. Agricultural and Forest Meteorology 34:241-252.

Manrique-L A (1992) Potato production in the tropics: Crop requirements. Journal of Plant Nutrition 15:2679-2726. 
Manrique L A, Kiniry J R, Hodges T, Axness D S (1991) Dry matter production and radiation interception of potato. Crop Science 31:1044-1049.

Manrique L A, Hodges T (1989) Estimation of tuber initiation in potatoes grown under tropical environments based on different methods of computing thermal time. American Potato Journal 66:425-436.

Marinus J, Bodlaender K B A (1975) Response of some potato varieties to temperature. Potato Research 18:189-204.

Menzel C M (1985a) Tuberization in potato at high temperatures: interaction between temperature and irradiance. Annals of Botany 55:35-39.

Menzel C M (1985b) The control of storage organ formation in potato and other species. Field Crop Abstracts 38:527-537.

Menzel C M (1983) Tuberization in potato at high temperatures: interaction between root and shoot temperatures. Annals of Botany 52:65-69.

Midmore D J (1992) Potato production in the tropics. Pages 728-793 in Harris P M (Ed.) The Potato Crop. Chapman \& Hall, London, UK.

Midmore D J (1988) Potato in the hot tropics I. Soil temperature effects on emergence, plant development and yield. Field Crops Research 8:255-271.

Midmore D J (1984) Potato in the hot tropics I. Soil temperature effects on emergence plant development and yield. Field Crops Research 8:225-271.

Moorby J (1968) The influence of carbohydrate and mineral nutrient supply on the growth of potato tubers. Annals of Botany 32:57-68.

$\mathrm{Ng} \mathrm{E}$, Loomis R S (1984) Simulation of Growth and Yield of the Potato Crop. Simulation Monographs, Pudoc, Wageningen, The Netherlands.

Nishibe S, Iwama K, Nakaseko K (1988) Annual variation of growth and its relation to meteorological factors in potato plants. Japan. J. Crop Sci. 57:505-511.

Randeni G, Caesar K (1986) Effect of soil temperature on the carbohydrate status in the potato plant (S. tuberosum L.). Journal of Agronomy and Crop Science 156:217-224.

Regel P A, Sands P J (1983) A Model of the development and bulking of potatoes. IV daylength, plant density and cultivar effects. Field Crops Research 6:1-23.

Reynolds M, Ewing E E (1989) Effects of high air and soil temperature stress on growth and tuberization in Solanum Tuberosum. Annals of Botany 64:241-247.

Sale P J M (1979) Growth of potatoes (Solanum Tuberosum) to small tuber stage as related to soil temperature. Australian Journal of Agricultural Research 30:667-677.

Sale P J M (1974) Productivity of vegetable crops in a region of high solar input. III. Carbon balance of potato crops. Australian Journal of Plant Physiology 1:283-296.

Sands P J, Hacket C, Nix H A (1979) A model for the development and bulking of potatoes (Solanum Tuberosum L.) I. Derivation from well-managed field crops. Field Crops Research 2:309-331.

Snyder R G, Ewing E E (1989) Interactive effects of temperature, photoperiod, and cultivar on tuberization of potato cuttings. HortScience 24:336-338.

Spitters C J T (1990) Crop growth models: Their usefulness and limitations. Acta Horticulturae 267:349-368.

Spitters C J T (1987) An analysis of variation in yield among potato cultivars in terms of light absorbtion, light utilization and dry matter partitioning. Acta Horticulturae 214:71-84.

Spitters C J T, Schapendonk A H C M (1990) Evaluation of breeding strategies for drought tolerance in potato by means of crop growth simulation. Plant and Soil 123:193-203.

Struik P C, Ewing E E (1995) Crop physiology of potato (Solanum tuberosum): Responses to photoperiod and temperature relevant to crop modelling. Pages xxx in Haverkort A J, MacKerron D K L (Eds.) Ecology and Modelling of Potato Crops under Conditions Limiting Growth. Kluwer Academic Publishers, Dordrecht, The Netherlands.

Struik P C, Geertsema, J, Custers C H M G (1989a) Effects of shoot, root and stolon temperature on the development of the potato (Solanum tuberosum L.) plant. I. Development of the haulm. Potato Research 32:133-141.

Struik P C, Geertsema J, Custers C HM G (1989b) Effects of shoot, root and stolon temperature on 

the development of the potato (Solanum tuberosum L.) plant. II. Development of stolons. Potato
Research 32:143-149.

Struik P C, Van Heusden E, Burger-Meijer K. (1988) Effects of short periods of long days on the development, yield and size distribution of potato tuber. Netherlands Journal of Agricultural
Science 36:11-22.

Van Oijen M, De Ruijter F.J., Van Haren R.J.F., Responses of field grown Potato cultivar to cyst nematodes at three levels of soil compaction 1: leaf area dynamics, photosynthesis and crop
growth (submitted).

Van der Zaag P, Demagante A L, Acasio R, Domingo A, Hagerman H (1986) Response of Solanum potatoes during the different seasons in an isohyperthermic environment in the Philippines.
Tropical Agriculture 63:229-239.

Tropical Agriculture 63:229-239.

Van Keulen H, Stol W (1995) Agro-ecological zonation for potato production. Pages xxx in Haverkort A J, MacKerron D K L (Eds.) Ecology and Modelling of Potato Crops under Conditions Limiting Growth. Kluwer Academic Publishers, Dordrecht, The Netherlands.

Vos J, Oyarzun P J (1987) Photosynthesis and stomatal conductance of potato leaves - effects of leaf age, irradiance and leaf water potential. Photosynthesis Research 11:253-264.

Wheeler R M, Tibbitts T W (1987) Utilization of potatoes for life support systems in space: III. Productivity at successive harvest dates under 12-h and 24-h photoperiods. American Potato
Journal 64:311-320. Wolf S, Marani A, Rudich J (1990) Effect of temperature and photoperiod on assimilate partitioning
in potato plants. Annals of Botany 66:513-520. Yandell B S, Najar A, Wheeler R, Tibbitts T W (1988) Modelling the effects of light, carbon dioxide,
and temperature on the growth of potato. Crop Science 28:811-818. 